\title{
CULTURE AND WORLD ORDER
}

I

Culture, more specifically cultural identity, is a dialectical phenomenon in the sense of the philosophy of mind as it is embodied, for instance, in the tradition of idealism. It must not be understood as a never

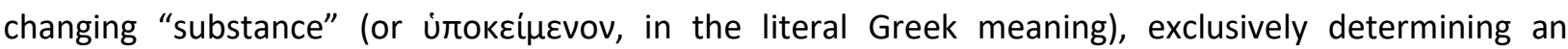
individual's or a community's world-and self-perception. Culture is constantly being shaped and reshaped by interaction with other cultures. Thus, "identity" is not something static, but a never-ending process that stretches over space and time, a continuous flow of world perceptions - "life-worlds," to use a phenomenological term - through the history of mankind.

World order is the status of relations between states, peoples and cultures (or civilizations, in the most universal sense) at a given moment in history. In our era of globalization, it is an ever more complex system of interaction and rules, related to it, that - ideally - results in a balance of power, but often in history, as in the present transitory phase, has been characterized by its absence.

It is exactly in the latter case - namely in the absence of a balance of power - that the role and position of culture in the global interplay of forces is most fragile and delicate, but at the same time also indispensable - as is now the case - for the transition from a unipolar to a multipolar order. Only the latter is conducive to a stable and peaceful co-existence among a multitude of political and cultural actors, or states and peoples, in our ever more interconnected "global village," indeed our community of destiny.

In a unipolar constellation, the imbalance of power relations is - almost unavoidably, one might say, as far as the psychology of power is concerned - exploited by the dominant actor for the sake of "canonizing" his own position. As has been evident throughout history, hegemonial powers indeed tend to negate the "dialectics of cultural identity" in a twofold manner:

(a) Cultural exclusivism: They make efforts to "civilize" those that are subordinated to them by imposing their peculiar worldview and system of values, thus marginalizing "lesser" cultures, stigmatizing them as "primitive." A claim to cultural universality has indeed been typical of imperial rule, and in particular of the self-perception and practice of colonial empires. This has been even more so in cases where polities have been able to acclaim a status of effectively "global" rule of the then-known world.

(b) Instrumentalization of culture: At the same time, the dominant player - in many, though not all, instances - uses its own culture as a tool to legitimize and perpetuate his rule. This somehow ideological strategy goes in tandem with a trend towards cultural uniformity, which also has become a characteristic of $21^{\text {st }}$ century economic globalization.

It would be worthy of some further reflection as to whether, and in what sense, "culture" may indeed be seen, or characterized, as an intrinsic element of power, as is also evident in the "soft power" approach of the recent international relations discourse. Can culture adequately be perceived as one aspect of a broad spectrum of power relations that includes, as far as states and world order are concerned, the use of armed force as last resort? Or would this imply its "instrumentalization" in the above-described sense? 
Whatever the answer to these questions about the structural relationship, or interdependence, between "culture" and "power" and its implications for the community of nations will be, the dialectics of cultural identity, if negated by those in the most powerful positions internationally, will always return in another shape and form - as an "unintended consequence" of the self-assertion of an era's dominant players and their strategy to imprint their mark on the global order.

An all-encompassing projection of power, including the claim to cultural supremacy, may somehow trigger a process that activates, so to speak, that very dialectics. Especially under conditions of unequal power relations and social injustice, whether perceived or real, a forceful assertion of a cultural paradigm, its propagation as universal standard, may provoke an attitude of resistance and lead to a new selfawareness of those who are expected to adapt to another culture - on the basis of a claim of universal values represented by that culture. This actio-reactio scheme represents the very nature of the dialectics of cultural identity.

The dynamics of this process were manifest in the process of decolonization since the 1960s, especially on the African continent where intellectuals such as Aimé Césaire or Léopold Sédar Senghor, the founding president of Senegal and philosopher of négritude, reminded Europe, in particular, of its cultural arrogance, and identified the core issues of cultural alienation between the colonizing and colonized world. I vividly remember my conversations with Senghor in the early 1970s and his enthusiastic support for the International Progress Organization's conference (in 1974) on "The Cultural Selfcomprehension of Nations."

In recent decades, around the turn of the century, this dialectical process has been particularly obvious in relations between the Muslim and Western or, more generally, secular world, albeit in a different kind - one that now appears to shake the very foundations of world order und challenge the underlying paradigm of peaceful co-existence. The emergence of Islamic revival movements - whether Sunni- or Shia-inspired - has marked a process of ever increasing cultural alienation, often fuelled by conflicts of interests and geopolitical aspirations. It is important to stress that the so-called "clash of civilizations" is a consequence, not the origin, of these "clashes of interests" on the geopolitical scene.

One of the most consequential events, in that regard, was the Islamic revolution in Iran in 1979. Though dismissed by most pundits outside of the country, a broad popular movement eventually prevailed against an Emperor who considered himself invulnerable - as ally of some of the most powerful countries of the time - and who had arrogantly lectured leaders in Europe about political stability and good statesmanship. Another example, with far-reaching consequences still affecting us today, are the developments triggered by the Soviet invasion of Afghanistan in that same year (1979) that eventually resulted in the collapse of that country's socialist régime in 1989, one of the defining moments upon the end of the Cold War, and later the emergence of the "Islamic Emirate of Afghanistan" in 1996. The most serious development, however, appears to be the recent emergence of a so-called الدولة الإسلامية, or "Islamic State" (IS), in the course of the disintegration of the state system in Iraq and, partially, also Syria, with ramifications in the wider Arab and Muslim world, whether in Libya, Egypt, Tunisia, Mali, Nigeria or even Mindanao in the Southern Philippines. Whichever its actual status may be in terms of governance and territorial control, this new entity understands itself as the very antithesis to Western (secular) civilization. A quick glimpse at this "state's" quasi-official magazine, Dabiq, especially its theological and 
doctrinal articles, makes this more than obvious. The IS derives its strength not only from the alienation of Sunnis in Iraq and Syria (since the events of 2003 and 2011 respectively), and the centuries-old SunniShia rift, but from a deep sense of cultural humiliation that accumulated over decades of colonial tutelage and foreign, essentially Western, supremacy in the region - in fact since the disintegration of the Ottoman Empire at the end of World War I. These events have contributed, and still are contributing, to a dramatic change in the regional power constellation, and have triggered a chain of events that has now also reached Europe.

As these and many other examples drastically demonstrate, a claim to cultural superiority, backed by measures of conventional power, may, so to speak, "dialectically" produce a counter-claim, or a new, more radical form of cultural exclusivism. Especially as religious belief, one of the most decisive factors of cultural identity, is concerned, time and again efforts at "reeducation" - by way of "enlightenment" or "modernization" campaigns - have proven unsuccessful in the long term. This is a lesson one can learn, among others, from the collapse of Communism, and it is a lesson that should be heeded by all those global actors who have embarked on a strategy of exporting their culture in the name of universal values. As Amy Chua ("Day of Empire") has brilliantly shown, even the most powerful actors in history, the global empires of their time, have been subjected to that law. Only those that were prepared to include cultures and religions on the territory they ruled into their realm, to accept and integrate distinct identities instead of trying to exclude and eventually eradicate them, were able to preserve their power and guarantee a stable order over a longer period of time, often over centuries. The destiny of radical exclusivist approaches, however, has almost always been their sudden demise. This, it is to be hoped, will also be the fate of the most exclusivist approach, so far, in recent history, namely that of IS.

III

A just and stable world order will require mutual respect among cultures and civilizations - and this is even more so in our era of global interconnectivity. Culture must not be made an instrument of world order, or a tool to enforce obedience from the less powerful; it has to be accepted as expression of $a$ community's identity on the basis of mutuality. Neglecting this principle may trigger a cycle of aggressive self-assertion, which it will be difficult to arrest. Trying to recreate, or "reinvent," other cultures in the image of a dominant one will ultimately be an exercise in self-deception. No one can arrest history and establish his paradigm for the rest of the world until the end of times. The world has rather quickly woken up from the post-Cold War proclamation of the "End of History."

A stable world order requires a balance of power in a multidimensional sense. In the $21^{\text {st }}$ century, and under the conditions of globalization, this is expected to be a multipolar one, based on a system of rules agreed upon among sovereign nations. Sovereign equality of states should be complemented by sovereign equality of cultures and civilizations if "culture wars" - that always in history have carried the risk of "perpetual" conflict - are to be avoided. It goes without saying that the principle of equality cannot be defined, and practiced, without mutuality (mutual respect) and that there can be no tolerance vis-àvis those who reject it. This is the dilemma the world is faced with when cultural paradigms exclude each other in the name of universality.

Good statesmanship on a global scale will try to avoid actions that trigger an aggressive assertion of identity - as difficult and delicate a task as this may be in today's multicultural world. World order - and 
peace as its ideal characteristic - is ultimately also a function of culture, implying mutual respect among different expressions of identity. Negation of this truth may bring a state of global disorder - with no end in sight. 